\title{
Evaluation of hearing loss in patients with neonatal unconjugated hyperbilirubinemia
}

\author{
Yenidoğan indirekt hiperbilirubinemili hastalarda işitmenin değerlendirilmesi \\ Baki Korkmaz', İmran Şan², Murat Kar', İsmail İynen² \\ ${ }^{\prime}$ Department of Otorbinolaryngology, Şanhurfa Balkklgöl State Hospital, Şanluurfa, Turkey \\ ${ }^{2}$ Department of Otorbinolaryngology, Faculty of Medicine, Harran University, Şanluurfa, Turkey \\ ${ }^{3}$ Department of Otorbinolaryngology, Antalya Kumluca State Hospital, Antalya, Turkey
}

\begin{abstract}
Objective: To investigate how the various bilirubin levels on patients with neonatal unconjugated hyperbilirubinemia affect the hearing loss in early periods.

Methods: One hundred twenty one infants (89 with indirect hyperbilirubinemia and 32 healthy subjects) were included in the study. Seven working groups (Group I-VII) were formed in accordance with their bilirubin levels, which were $19.9 \mathrm{mg} / \mathrm{dl}$ and below, 20.0-29.9 mg/dl, 30 $\mathrm{mg} / \mathrm{dl}$ and over, $10.95-38.08 \mathrm{mg} / \mathrm{dl}$ and premature, $20.01-38.08 \mathrm{mg} / \mathrm{dl}$ and with no exchange transfusion, $24.7-46.65 \mathrm{mg} / \mathrm{dl}$ and with exchange transfusion and control group, respectively. Each infant was controlled in terms of hearing tests including tympanogram, stapes reflex, otoacoustic emission at least 3 times within 12 months period. The auditory brainstem responses and free area behavioral threshold tests were performed on the cases which were found to have hearing loss by those tests.

Results: Stapes reflex could not be found on 1, 6, 3, 1, 4, 7 infants in the Groups of I-VI, respectively. Cochlear response in otoacoustic emission was not observed on 2, 8, 7, 2, 5, 11 infants, respectively. In the auditory brainstem responses, wave $V$ was not found on $1,4,1,1$, 3,2 infants, respectively. Free area behavioral threshold test performed on 6 patients whose auditory thresholds were thought to be low revealed normal threshold in 5 patients and extremely sensorineural hearing loss in 1 patient. No significant difference was observed among all working groups in terms of hearing loss.

Conclusion: In infants exposed to indirect hyperbilirubinemia (>20 $\mathrm{mg} / \mathrm{dl}$ ) for a long time, cochlear and auditory functions could be affected. Hearing loss, which is one of the probable complications of postnatal bilirubin encephalopathy, is required to be followed up closely for early diagnosis.
\end{abstract}

Key words: Hearing loss, neonatal, indirect hyperbilirubinemia, hearing screening, cochlear function.

\begin{abstract}
Özet
Amaç: Yenidoğan indirek hiperbilirubinemili hastalarda erken dönemde farklı bilirubin düzeylerinin işitme üzerine etkilerini araştırmak.

Yöntem: Seksen dokuz indirek hiperbilirubinemili ve 32 sağlıklı bebek olmak üzere toplam 121 bebek bu çalışmaya alındı. Yedi çalışma grubu (Grup I-VII) sırası ile bilirubin seviyeleri $19.9 \mathrm{mg} / \mathrm{dl}$ ve altında, $20.0-29.9 \mathrm{mg} / \mathrm{dl}, 30 \mathrm{mg} / \mathrm{dl}$ ve üzerinde, $10.95-38.08 \mathrm{mg} / \mathrm{dl}$ ve prematüre, 20.01-38.08 mg/dl ve exchange transfüzyon (kan değişimi) yapılmamış, $24.7-46.65 \mathrm{mg} / \mathrm{dl}$ ve exchange transfüzyon yapılmış ve kontrol grubu olarak belirlendi. Her bebek 0-12 aylık dönem içerisinde en az 3 defa timpanogram, stapes refleksi ve otoakustik emisyon testleri yönünden kontrole tabii tutuldu. İşitme kaybı tespit edilen olgulara işitsel beyin sapı cevapları ve serbest saha davranışsal eşik tespiti işitme testleri yapıldı.

Bulgular: Stapes refleks analizlerinde Grup I-VI'da sirasıyla, 1, 6, 3, 1, 4, 7 bebekte refleks tespit edilemedi. Otoakustik emisyon analizinde Grup I-VI'da sırasıla, 2, 8, 7, 2, 5, 11 bebekte koklear cevap tespit edilmedi. İşitsel beyin sapı cevaplarında Grup I-VI'da sırasıyla, 1, 4, 1, 1, 3, 2 bebekte $V$. dalga tespit edilmedi. Bu testler sonucu işitme eşiğinin düşük olduğu düşünülen 6 hastaya yapılan serbest saha davranışsal eşik testi sonrası 5 hastada normal eşik saptanırken, 1 hastada çok ileri derecede sensorinöral işitme kaybı tespit edildi. Bütün çalışma grupları arasında işitme kaybı yönünden anlamlı fark bulunmadı. Sonuç: Uzun süre indirek hiperbilirubinemiye (>20 mg/dl) maruz kalan bebeklerde koklear ve ișitsel fonksiyonlar etkilenebilir. Doğum sonrası bilirubin ensefalopatisi komplikasyonlarından olan işitme kaybının erken tanısı için yakın takip gerekmektedir.
\end{abstract}

Anahtar sözcükler: İşitme kaybı, yenidoğan, indirek hiperbilirubinemi, işitme taraması, koklear fonksiyon.
Correspondence: Baki Korkmaz, MD. Şanlıurfa Balıklıgöl Devlet Hastanesi, Kulak Burun Boğaz Hastalıkları Kliniği, Şanlıurfa, Turkey.

e-mail: korkmazbaki@yahoo.com

Received: February 25, 2013; Accepted: March 27, 2013; Published online: November 1, 2013
Online available at:

www.jmedupdates.org doi:10.2399/jmu.2013002001 QR code: 
Jaundice is the visible form of chemical hyperbilirubinemia which is one of the frequently causes of neonatal hearing loss. ${ }^{[1]}$ Since hearing loss is not a visible disorder, the adverse effects of hyperbilirubinemia on infants have not attracted attention. Infants who had been diagnosed and received voice amplification therapy and special training in the early period of their disease have been observed and the investigators reported that they had demonstrated psychological development and academic achievements in these infants nearing to those of their healthy peers. ${ }^{[2]}$

In our country, very limited number of studies have investigated the relationship between levels of bilirubin and toxicity. ${ }^{[3,4]}$ In this study, evidence of bilirubin toxicity during postnatal 0-12 months in infants who had bilirubin levels $\geq 12.9 \mathrm{mg} / \mathrm{dl}$ and received phototherapy with or without blood exchange transfusion according to the treatment protocol have been investigated using hearing tests as auditory brainstem response evoked potentials (ABR), evoked otoacoustic emissions (EOAE), tympanogram, stapes reflex and neurological examination findings with the intention to identify patients with hearing loss.

\section{Materials and Methods}

This study was conducted in the Clinics of ENT Department and Neonatal Unit of the Department of Pediatrics of Harran University Faculty of Medicine, Neonatal Unit of the Clinics of Pediatrics of Şanlıurfa State Hospital and Neonatal Unit of Şanlıurfa Gynecologic Diseases and Maternity Hospital. Otherwise healthy term infants with serious hyperbilirubinemia without any evidence of hemolysis who were hospitalized and monitored with the indication of jaundice in their neonatal period were evaluated between 0-12 months of their lives as for bilirubin neurotoxicity using hearing, developmental and neurological tests and their results were compared with those of the control group.

\section{Selection Criteria for the Hyperbilirubinemic Group}

Characteristics of the neonatal period: (1) Birth weight $\geq 2500$ g; gestational age >37 weeks; (2) Direct Coombs test result negative and without any evidence of hemolysis (absence of anemia, reticulocytosis and findings of hemolysis in the peripheral blood smear); (3) Healthy state (without any metabolic, genetic or congenital disorders or abnormal conditions which might increase bilirubin neurotoxicity or interfere with the other test results of the infants as birth asphyxia, acidosis, sepsis, seizures, intracranial bleeding); (4) Born as a single delivery; (5) Serum indirect bilirubin level $>12.9 \mathrm{mg} / \mathrm{dl}$ at admission to the hospital; (6) Infants whose serum indirect bilirubin levels could only decline to $20-24 \mathrm{mg} / \mathrm{dl}$ with phototherapy, but received the same treatment for an additional 4-6 hours till blood exchange transfusion with resultant drop of bilirubin levels down to $<20 \mathrm{mg} / \mathrm{dl}$ were included in the study if they hadn't received exchange transfusion despite their bilirubin levels rised again up to $>25 \mathrm{mg} / \mathrm{dl}$ despite during maintenance phototherapy.

\section{Selection Criteria for the Control Group}

Characteristics of the neonatal period: (1) Birth weight $\geq 2500$ g; gestational age $>37$ weeks; (2) Absence of any visible jaundice during the neonatal period or noticeable jaundice characterized by bilirubin levels below physiologic limits $(<12.9 \mathrm{mg} / \mathrm{dl})$ which did not necessitate phototherapy or exchange transfusion; (3) Healthy infants (with characteristics similar to the study group) delivered as a single birth.

Characteristics related to the study period: (1) Infants in the same age group and health state as those in the study group; (2) Infants who were referred to the outpatient clinics with simple complaints not affecting their hearing ability; (3) Infants of the parents who had volunteered to take part in the study were included in the control group.

\section{Data Collection Methods}

A pediatrician performed detailed neurologic examinations on the infants included in the study and the control groups. Besides, their gestational ages, birth weights, methods of delivery, ages, gender, parental consanguinity (if any), residential area (city, shantytown, urban or rural area) were recorded. Before hospitalization, both ears of the infants were examined with an otoscope. Plugs retained (if any) within the external auditory canal were removed. Tympanograms of the infants with normal examination findings were obtained, their stapes reflexes were controlled and EOAE tests were performed. If not available, additionally tympanograms, stapes reflex and EOAE tests were requested. Infants were kept sleepless overnight, then $\mathrm{ABR}$ tests were performed while they were in deep sleep. In addition, transient EOAE test was applied to investigate the impact of bilirubin neurotoxicity on their cochleae.

\section{Statistical Analyses}

Data were analyzed using the Statistical Package for Social Sciences 11.0 for Windows (SPSS Inc., Chicago, IL, USA). The results for all items were expressed as mean \pm SD, assessed within a $95 \%$ reliance and at a level of 
$\mathrm{p}<0.05$ significance. Parametric tests were applied to data of normal distribution and non-parametric tests were applied to data of questionably normal distribution. Student t-test was used to compare independent groups. The distribution of categorical variables in both groups was compared using Pearson chi-square test.

\section{Results}

Among infants followed up between July 2007 and July 2008 with the indication of indirect hyperbilirubinemia, 30 hyperbilirubinemic infants whose bilirubin levels were above $12.9 \mathrm{mg} / \mathrm{dl}$ and 30 healthy control infants completed the study.

Data related to the infants in the control and the study groups, such as gestational age, birth weights, age during the study period and duration of breast-feeding, method of delivery, gender and sociodemographic characteristics of the family are given in Tables 1 and 2. A statistically significant difference was not detected between both groups regarding all of these parameters $(\mathrm{p}>0.05)$.

Mean peak serum bilirubin level of the infants in the study group detected before phototherapy did not differ statistically significantly between male and female infants $(\mathrm{p}=0.79)$. When infants were divided into 2 groups based on their serum bilirubin levels, 11 male and 11 female infants had bilirubin levels between 20 and $22 \mathrm{mg} / \mathrm{dl}$, while serum bilirubin concentrations between 22.1-24 $\mathrm{mg} / \mathrm{dl}$ were detected in 5 male and 3 female infants with- out any statistically significant difference between infants in two distinct subgroups of hyperbilirubinemia $(\mathrm{p}=0.56)$ (Table 3).

In none of the cases in both groups neurologic examination findings suggested preexisting chronic bilirubin encephalopathy. Any developmental delay was not detected in any infant as assessed by total and subtests of Ankara Developmental Screening Test. A borderline developmental delay was detected in one infant in both groups as assessed by fine motor subtest Any difference was not found between mean $\mathrm{T}$ scores of both groups $(\mathrm{p}=0.56)$. Besides mean $T$ scores of male $(\mathrm{p}=0.12)$ and female $(\mathrm{p}=0.5)$ infants were similar. In the study group, a correlation between serum bilirubin levels and $\mathrm{T}$ scores could not be demonstrated ( $\mathrm{p}=0.55, \mathrm{r}=-0.114)$.

Otoacoustic emissions of both ears of all children in both groups were measured. In Type A tympanograms of each infants peaks in the range of normal pressure area were detected and the presence of ipsi- and contraacoustic reflexes was determined. In the auditory evoked brain stem response potential test, a total of 240 clicks (each) at an intensity of $80 \mathrm{~dB} \mathrm{nHL}$ were applied on both ears of each infant. Besides to confirm that hearing threshold of each ear is below $40 \mathrm{~dB} \mathrm{nHL}$, thresholds of click-evoked stimuli were determined. In both groups auditory threshold levels were within normal limits. In both groups, any statistically significant difference between latencies of I, III and V waves, and mean interpeak intervals recorded separately for

Table 1. Clinical characteristics of the infants in both groups.

\begin{tabular}{|c|c|c|c|}
\hline & $\begin{array}{l}\text { Study group }(n=30) \\
\text { Mean } \pm \text { SD (range) }\end{array}$ & $\begin{array}{l}\text { Control group }(n=30) \\
\text { Mean } \pm \text { SD (range) }\end{array}$ & $p$ value \\
\hline Gestational age* (wks) & $39.0 \pm 1.0(37-40)$ & $39.1 \pm 1.0(37-41)$ & 0.71 \\
\hline Age during the study period* (mos) & $35.9 \pm 14.3(21-70)$ & $39.0 \pm 12.9(24-68)$ & 0.50 \\
\hline Duration of breast-feeding* (mos) & $9.2 \pm 7.4(0-24)$ & $9.8 \pm 7.1(1-24)$ & 0.38 \\
\hline \multicolumn{4}{|l|}{ Method of delivery } \\
\hline \multicolumn{4}{|l|}{ Gender } \\
\hline Male & $16(53 \%)$ & $18(60 \%)$ & 0.79 \\
\hline Female & $14(47 \%)$ & $12(40 \%)$ & \\
\hline \multicolumn{4}{|c|}{ Percentile of body weight adjusted to age } \\
\hline $10-50 \%$ & $15(50 \%)$ & $15(50 \%)$ & 1.00 \\
\hline $51-97 \%$ & $15(50 \%)$ & $15(50 \%)$ & \\
\hline
\end{tabular}

The results were expressed as *mean \pm standard deviation (min-max) or numbers and percentages (\%). 
Table 2. Sociodemographic characteristics of the families in both groups.

\begin{tabular}{lcc}
\hline & $\begin{array}{c}\text { Study group } \\
\mathbf{n}(\%)\end{array}$ & $\begin{array}{c}\text { Control group } \\
\mathbf{n}(\%)\end{array}$ \\
\hline $\begin{array}{l}\text { Employment status of the mother } \\
\text { Working }\end{array}$ & $16(53 \%)$ \\
Housewife & $16(53 \%)$ & $14(47 \%)$ \\
Educational level of the mother & $14(47 \%)$ & $5(17 \%)$ \\
$\quad$ Primary-middle & $10(33 \%)$ & $17(57 \%)$ \\
Lycée & $11(37 \%)$ & $8(26 \%)$ \\
High school-university & $9(30 \%)$ & 4.00 \\
Educational level of the father & & $4(13 \%)$ \\
Primary-middle & $7(23 \%)$ & $9(30 \%)$ \\
Lycée & $11(37 \%)$ & $17(57 \%)$ \\
High school-university & $12(40 \%)$ & $18(60 \%)$ \\
Caretaker of the infant (person, institution) & & $6(20 \%)$ \\
Mother & $14(47 \%)$ & $6(20 \%)$ \\
Baby-sitter & $10(33 \%)$ & 0.22 \\
Kindergarten & $6(20 \%)$ & $22(74 \%)$ \\
Residential area of the family & & $7(23 \%)$ \\
$\quad$ City & $24(80 \%)$ & $1(3 \%)$ \\
Rural area & $4(13 \%)$ & 0.47 \\
Shantytown & $2(7 \%)$ & 0.54 \\
\hline
\end{tabular}

right and left ears of each infant was not found ( $p>0.05)$. Still comparisons between study and control groups did not reveal any significant difference as for latencies of I, III and $\mathrm{V}$ waves and mean I-III, I-V and III-V interpeak intervals (Table 4). Any intergroup difference was not detected when the same parameters were compared separately for male and female infants. In the study group, a statistically significant correlation was not found between serum bilirubin levels, latencies of I, III and V waves, and I-III, I-V and III-V interpeak intervals recorded in the ABR test $(\mathrm{p}>0.05)$.

\section{Discussion}

One or more than one defect is found in the bilirubin metabolism and transport of the normal infant. ${ }^{[5]}$ During
Table 3. Neonatal total serum bilirubin levels of the infants in the study Group I.

\begin{tabular}{lccc}
\hline & Male $(\mathbf{n}=\mathbf{1 6})$ & Female $(\mathbf{n}=\mathbf{1 4})$ & Total $(\mathbf{n = 3 0})$ \\
\hline TSB level $(\mathrm{mg} / \mathrm{dl})($ range $)$ & $21.7 \pm 0.9$ & $21.8 \pm 1.0$ & $21.8 \pm 1.0$ \\
& $(20-23.7)$ & $(20.4-24)$ & $(20-24)$ \\
$20-22 \mathrm{mg} / \mathrm{dl}(\%)$ & $11(50 \%)$ & $11(50 \%)$ & $22(73 \%)$ \\
$22.1-24 \mathrm{mg} / \mathrm{dl}(\%)$ & $5(62.5 \%)$ & $3(37.5 \%)$ & $8(27 \%)$ \\
\hline
\end{tabular}

TSB: Total serum bilirubin

the first week of life of almost every newborn, physiologic hyperbilirubinemia develops, however only $45-65 \%$ of the term infants "visible jaundice" occurs. Indeed, in older children and adults, jaundice become apparent on the skin

Table 4. Comparison between the latencies of waves I, III, and V and mean I.-III., I.-V. and III.-V. interpeak intervals in the study and the control groups. *

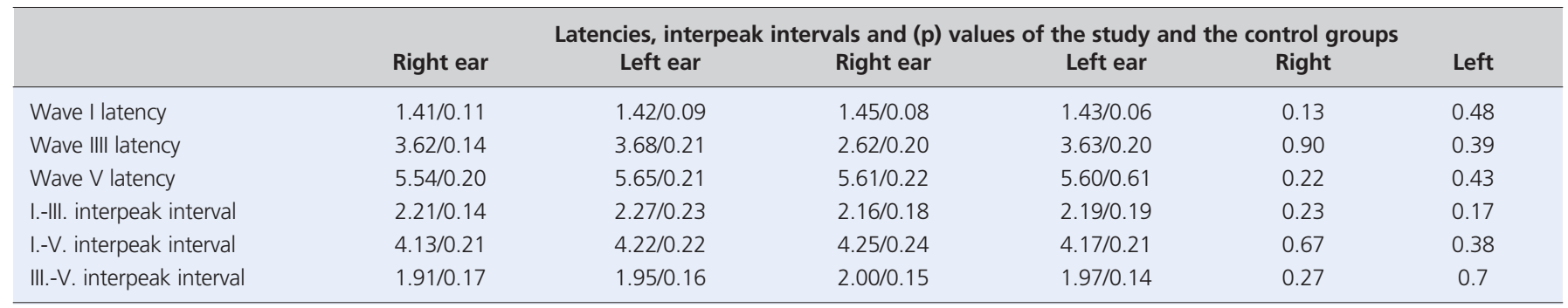

*All values are expressed as milliseconds. 
and sclera when serum bilirubin levels reach to $2 \mathrm{mg} / \mathrm{dl}$, while in newborns their levels should exceed $5 \mathrm{mg} / \mathrm{dl}$ to become visible. ${ }^{[6]}$

Since 1959, it has been acknowledged that bilirubin is not harmful in healthy term and non-hemolytic babies and these babies maintain their normal developmental process even in case of hyperbilirubinemia $(>20 \mathrm{mg} / \mathrm{dl})$ without resorting to exchance transfusion. ${ }^{[7]}$ It has been demonstrated that phototherapy applied on infants whose bilirubin levels were monitored during postnatal period, decreased serum bilirubin levels effectively and also when compared with the control group, any difference in the incidence of cerebral palsy, mental retardation, seizures and auditory and visual abnormalities was not detected when these infants were followed up till 6 years of age. ${ }^{[8]}$ Also in our study, any difference was not found between the control group and the age-matched study group with similar health state characteristics excepting neonatal jaundice in the latter group.

As a known fact, auditory canal of the newborns is especially vulnerable to the effects of bilirubin toxicity and even moderately increased serum bilirubin levels affect auditory pathways. Apparent abnormalities in ABR test results caused by hyperbilirubinemia include absence of waves, prolongation of wave and interpeak latencies or increase in their threshold. Interpretation of the hearing loss is based on measurement of threshold sensitivity, absence or presence of $\mathrm{V}$. wave. However demonstration of longer latencies before development of complete or partial hearing loss has been suggested as a premature and reversible sign of bilirubin encephalopathy. Even though most of the studies have demonstrated evidence of encephalopathy in the brain stem, some other studies have also revealed cochlear or peripheral involvement or both in cases of cerebral damage. They have also indicated that these different sites of involvement might be correlated with serum bilirubin levels. ${ }^{[9]}$ Besides, along with $\mathrm{ABR}$ test, OAE test which is more sensitive in demonstrating cochlear abnormalities has been used and potential cochlear effects of bilirubin levels have been analyzed. ${ }^{[9,10]}$ As a concluding remark, regarding these test results, any difference between the hyperbilirubinemia and control groups has not been detected.

Changes in amplitudes and latencies in auditory brain stem responses in long-term follow-ups of the hyperbilirubinemic infants were firstly investigated in a study performed in the Hacettepe University. ${ }^{\left[{ }^{3]}\right.}$ The investigators retrospectively identified term infants who had bilirubin levels of $\geq 17 \mathrm{mg} / \mathrm{dl}$, grouped them according to their bilirubin levels and results of the Coombs test and analyzed those aged 8-13 years as for bilirubin neurotoxicity using physiconeurological tests, visual and auiditory evoked brain stem response potentials and a psychometric test. In their study long-term exposure to higher than $20 \mathrm{mg} / \mathrm{dl}$ serum bilirubin levels was demonstrated as the most important risk factor. As a conclusion of their study, the investigators interpreted that in term infants with direct Coombs test positivity, the conventional threshold level $(20 \mathrm{mg} / \mathrm{dl})$ for the indication of exchange transfusion should be maintained and in infants with Coombs test negativity, earlier recommendations should be entertained till establishment of new and safe criteria, especially in our country where periodic neonatal follow-ups are not adequately realized. ${ }^{[3]}$ When cases with similar bilirubin levels were compared with our study and control group, our control group did not differ from the control group of Hacettepe University. However, in our study, some neurological abnormalities were detected in patients with serum bilirubin levels of $20-22 \mathrm{mg} / \mathrm{dl}$ and $22-25 \mathrm{mg} / \mathrm{dl}$. In 4 out of 53 infants aged $8-13$ years, they detected a mild degree of choreoathetosis, however we didn't encounter this disorder in none of our study participants. Relatively smaller age of our study participants might create a difference in onset times of some abnormalities. Indeed choreoathetosis which is responsible for most of permanent neurological abnormalities is not generally seen in infants aged less than 18 months, onset of relevant symptoms can be delayed till 8-9 years of age. ${ }^{[5]}$ Besides, even though lack of any difference between mean latency values, increase in the percentage of abnormal ABR findings have been indicated in cases with bilirubin levels in excess of 20 $\mathrm{mg} / \mathrm{dl}$ when compared with the control group. However in certain groups, the frequency of these abnormalities can rise up to 50 percent and abnormality of these findings were determined in comparison with age-adjusted normal values. Since ABR test results can be affected by many factors as age, gender, ethnicity and race, which create important differences in practice, they should be compared with the ABR test results of a control group or pre- and posttreatment changes in the test values of the same infant should be interpreted. In our study, mean latencies of the study group did not differ from those of the control group.

In conclusion, even though scarce number of cases who had bilirubin levels between 22 and $24 \mathrm{mg} / \mathrm{dl}$ were included in the study, it has been demonstrated that in healthy terminfants who responded well to intensive phototherapy applied while preparing for blood exchange transfusions, refraining from exchange transfusion does not additionally contribute to brain damage incurred by hyperbilirubinemia 
and conventional threshold value of bilirubin for the indication of exchange transfusion can be elevated to $22-24 \mathrm{mg} / \mathrm{dl}$. However in our country neonatal jaundice and hemolytical disorders as G6PD deficiency are frequently seen, breastfeeding is prevalent and majority of babies are delivered at home. Besides premature discharges from hospitals are becoming a widespread practice. Therefore increasing threshold levels should not "desensitize" physicians and families of icteric infants against jaundice and the number of postnatal controls should not be decreased.

Conflict of Interest: No conflicts declared.

\section{References}

1. Neyzi O, Ertuğrul T. Pediatri. Vol. 1, 3rd ed. Istanbul: Nobel Tip Kitabevleri; 2002. p. 402-20.

2. Markides A. Age at fitting of hearing aids and speech intelligibility. Br J Audiol 1986;20:165-7.

3. Ozmert E, Erdem G, Topçu M, et al. Long-term follow-up of indirect hyperbilirubinemia in full-term Turkish infants. Acta Paediatr 1996;85:1440-4.
4. Duman N, Ozkan H, Serbetçioglu B, Ogün B, Kumral A, Avci M. Long-term follow-up of otherwise healthy term infants with marked hyperbilirubinaemia: should the limits of exchange transfusion be changed in Turkey? Acta Paediatr 2004;93:361-7.

5. Connolly AM. Clinical features of bilirubin encephalopathy. Clin Perinatol 1990;17:371-9.

6. Harris MC, Bernbaum JC, Polin JR, Zimmerman R, Polin RA. Developmental follow-up of breastfed term and near-term infants with marked hyperbilirubinemia. Pediatrics 2001;107:1075-80.

7. Newman TB, Maisels MJ. Does hyperbilirubinemia damage the brain of healthy full-term infants? Clin Perinatol 1990;17:331-58.

8. Scheidt PC, Bryla DA, Nelson KB, Hirtz DG, Hoffman HJ. Phototherapy for neonatal hyperbilirubinemia: six-year follow-up of the National Institute of Child Health and Human Development clinical trial. Pediatrics 1990;85:455-63.

9. Rhee CK, Park HM, Jang YJ. Audiologic evaluation of neonates with severe hyperbilirubinemia using transiently evoked otoacoustic emissions and auditory brainstem responses. Laryngoscope 1999;109:2005-8.

10. Huang L. Progressive hearing loss in an infant in a neonatal intensive care unit as revealed by auditory evoked brainstem responses. Auris Nasus Larynx 2002;29:187-90.

This is an open access article distributed under the terms of the Creative Commons Attribution-NonCommercial-NoDerivs 3.0 Unported (CC BYNC-ND3.0) Licence (http://creativecommons.org/licenses/by-nc-nd/3.0/) which permits unrestricted noncommercial use, distribution, and reproduction in any medium, provided the original work is properly cited.

Please cite this article as: Korkmaz B, Şan İ, Kar M, İynen İ. Evaluation of hearing loss in patients with neonatal unconjugated hyperbilirubinemia. J Med Updates 2013;3(2):45-50. 